\title{
The developmental variations of the sagitta otolith in the young and mature male of a hermaphrodite polynemidae fish, Eleutheronema tetradactylum (Shaw, 1804)
}

\author{
Soumen Roy ${ }^{1}$ \& Itika Bardhan² \\ ${ }^{1}$ City College, Department of Zoology. Kolkata, West Bengal, India. ORCID: http://orcid.org/0000-0002-3510-0947. \\ E-mail: soumenroyzoology@gmail.com (corresponding author) \\ 2 Women's College, Calcutta, Department of Zoology. Kolkata, West Bengal, India (Vidyasagar University, PG-Study Centre. \\ Midnapore, West Bengal, India). ORCID: http://orcid.org/0000-0002-9702-2913. E-mail: itikabardhan12@gmail.com
}

\begin{abstract}
The Eleutheronema tetradactylum is a protandrous, hermaphrodite, marine perciformes fish. The body length of this fish acts as an important diagnostic marker for male and female discrimination. The present study describes for the first time the ultrastructural characteristics on the medial surface of the sagitta otolith in different body size groups of males of E. tetradactylum (Polynemidae: Perciformes) using scanning electron microscopy. The sagitta is a spindle-shaped structure that includes a well-developed rostrum and a poorly developed antirostrum. The sulcus is ostio-pseudocaudal type, almost straight and devoid of the collum. The ostium is a well-developed, vase-shaped structure. The cauda includes the colliculum and a well-developed caudal bulb with several distinct growth stripes. The length of the caudal bulb is significantly correlated to the growth of the body size of the fish. The excisura major is indistinct and the excisura minor is absent. The cristae are distinct on both sides of the sulcus. The one-way ANOVA test revealed that the development of several sagitta features shows significant differences in various body size groups of $E$. tetradactylum. The growth of the sagitta length is more closely related to the fork length than the sagitta width. Therefore, the sagitta length and the caudal bulb length can be used as important predictors to evaluate the fish size. The cauda region of the sagitta in E. tetradactylum is unique as well as more decorative than those of another Polynemidae fish and other hermaphrodite, marine perciformes fishes. The sagitta characteristics of $E$. tetradactylum might be advantageous in the identification of the sex and the taxonomy of the hermaphrodite fish species.
\end{abstract}

Keywords. Sagitta; Protandrous fish; Scanning electron microscopy; Surface sculpture.

\section{INTRODUCTION}

The otolith is a calcareous anatomical structure in the inner ear of fish and assists in the sensation as well as the body balancing by stimulation of inner ear hair cells (Sanchez \& Martinez, 2017). In the taxonomic field, the fish species identification is significantly supported by the structural characteristics of the otolith due to its longer time of degradation (Rodríguez Mendoza, 2006; Vilizzi, 2018; Mitsui et al., 2020). The otolith includes one pair of sagittae, asteriscii and lapilli (Popper et al., 2005). The sagittae are the largest pair in size in fish groups (except, order Siluriformes and Cypriniformes) and are included in several species-specific characteristics (Harvey et al., 2000; Kontaş \& Bostanci, 2015; Yilmaz et al., 2015; Mehanna et al., 2016). The sagitta has two surfaces which are the lateral (outer) and medial surface (inner). The medial surface of the sagitta is well-decorated with different morpho-structural features (Smale et al., 1995; Jawad et al., 2018; Bardhan et al., 2021), which characteristically varies with the fish groups and various environmental factors in their respective habitats (Kumar et al., 2012; Omar \& AMohamed, 2016; Abdulsamad, 2017; Sanchez \& Martinez, 2017; Jawad et al., 2018; Pracheil et al., 2019). Several studies have dealt with the morphological descriptions of the sagitta of marine Perciformes fishes (Hunt, 1992; Smale et al., 1995; Gierl et al., 2018; Jawad et al., 2018), but no ultrastructural studies on the sagitta are available in the hermaphrodite perciformes fishes. Additionally, the perciform family Polynemidae have eight genera but the sagitta morphologies are only described by light micros- 
copy in only Polydactylus virginicus (Santificetur et al., 2017).

The E. tetradactylum (Polynemidae: Perciformes) is in fact a protandrous, hermaphrodite marine fish (Patnaik, 1967; Kowtal, 1972; Stanger, 1974; Motomura, 2004; Sadovy \& Liu, 2008). They act as functional male in their early part of life and then act as functional female for the later periods of life (Patnaik, 1967; Kowtal, 1972; Stanger, 1974; McPherson, 1997; Ballagh et al., 2012). The body size (fork length) of E. tetradactylum act as an important diagnostic marker for the male and female discrimination among the individuals (Kailola et al., 1993; McPherson, 1997; Ballagh et al., 2012). It is reported that the fork length of the fish around $24 \mathrm{~cm}$ act as a mature male and greater the body length acts as female (Stanger, 1974; Kailola et al., 1993; Motomura, 2004). Ballagh et al. (2012) briefly described the sagittae of Eleutheronema tetradactylum in a study of the relationship between the age and the growth of total body length of this fish. It has been stated that the development of the sagitta components (i.e., sulcus, ostium, rostrum, etc.) is associated with the body size (length/weight) groups of the sexually dimorphic fishes (Harvey et al., 2000; Jawad et al., 2018; Bardhan et al., 2021). However, there is no information regarding the developmental variations of the otolith morphologies among the young male and the mature male of the protandrous, hermaphrodite fishes. The present study aims to investigate detail ultrastructural characteristics of the sagitta otolith of the protandrous Eleutheronema tetradactylum (Shaw, 1804). A comparative developmental relationship of the various sagitta constituents between the young male and the mature male groups is conducted here. The results of the E. tetradactylum are also compared with the available data on the sagitta for a protandrous Polynemidae fish (Polydactylus virginicus) and three protandrous Sparidae fishes (Sparidentex hasta, Acanthopagrus berda, and Acanthopagrus latus).

\section{MATERIAL AND METHODS}

\section{Sample collection and grouping}

A total of 130 individuals of Eleutheronema tetradactylum (Shaw, 1804) (Polynemidae: Perciformes) were randomly collected from the fish market of Kolkata, West Bengal, India.The samples were identified by the Zoological Survey of India (ZSI), Kolkata, West Bengal, India. The body size of the individuals was examined by their fork length (i.e., the length from the anterior tip of the longest jaw to the median point of the caudal fin) (Önsoy et al., 2011; Butler et al., 2021) and was measured using a centimetre scale. The specimens were divided into four groups according to their fork length of the fishes (FL) (Jawad et al., 2011): group I (Gr-I), 11-12 cm (Mean: $11.55 \pm 0.30), n=25$; group II (Gr-II), 15-16 cm (Mean: $15.54 \pm 0.30), n=45$; group III (Gr-III), 19-20 cm (Mean: $19.58 \pm 0.31), n=35$; group IV (Gr-IV), 23-24 cm (Mean: $23.52 \pm 0.31), n=20$. The specimens in group IV were mature males and the individuals in other three groups were younger males.

\section{Collection of the sagitta otolith and scanning electron microscopy}

One pair of sagittae were removed from the saccule of the inner ear of each individual of the four groups (Ruck, 1976; Jawad et al., 2018), cleaned with water and $70 \%$ ethanol, and stored dry in individual plastic tubes. For ultrastructural studies on the medial (inner) surface of the sagittae, the right sagitta was examined (Bardhan et al., 2021). The sagittae were dried and mounted on an aluminium stub using double-sided carbon tape. The sagittae were gold-coated by DWARDS, RV5 coater, and analysed in an EVO18, ZEISS.

In the work, all the terminologies used for the description of the structural constituents of the medial surface of the sagitta are following Smale et al. (1995), Jawad (2007) and Bardhan et al. (2021).

\section{Morphometry and statistical analysis}

The measurements (mean value \pm SD) of the various sagitta constituents were taken for the sagittae from the four size groups using image-processing software "ImageJ 1.51t" (Wayne Rasband, NIH, USA). The weights of sagittae were taken with a digital weight machine (Mettler Toledo ME204). A normality test using ShapiroWilk test was applied to check the distributions of the studied sagitta constituents among the four groups. The test met the assumption of parametric analysis and a one-way ANOVA followed by Tukey's test was performed using XLSTAT statistical program to determine the statistical significance $(P<0.05)$ on the developmental differences on the growth of the studied sagitta features in the different life stages (young males to mature male) of E. tetradactylum.

\section{RESULTS}

\section{General morphology of the sagitta}

The sagitta of E. tetradactylum males is an oblong or spindle-shaped structure (Figs. 1, 2A-D). The medial surface of this sagitta is slightly convex and enriched with different structural features (Figs. 1, 2A-D, Tables 1-2). The ultrastructural characteristics of the various constituents on the medial surface of this sagitta is described with the following points.

\section{The sulcus}

The sagitta includes well-developed heterosulcoid and ostio-pseudocaudal type sulcus (Figs. 1, 2A-D, Table 1). The sulcus is mostly straight along its length and slightly bent near posterior end (Figs. 1, 2A-D, Table 1). The anterior end of the sulcus includes a vase-shaped ostial opening (Figs. 1, 2A). The posterior end of the sulcus contains slightly swollen, bulb-shaped, closed, caudal end- termed as the caudal bulb (Figs. 1, 2A-D, Table 1). 
The sulcus lacks the collum (Figs. 1, 2A-D). A distinct ' $V$ '-shaped ridge is developed near the junction of ostium and cauda in the sulcus groove (Figs. 1, 2A-D).

\section{The rostrum and antirostrum}

The rostrum part of the sagitta is well-developed while the antirostrum part is comparatively very shorter than

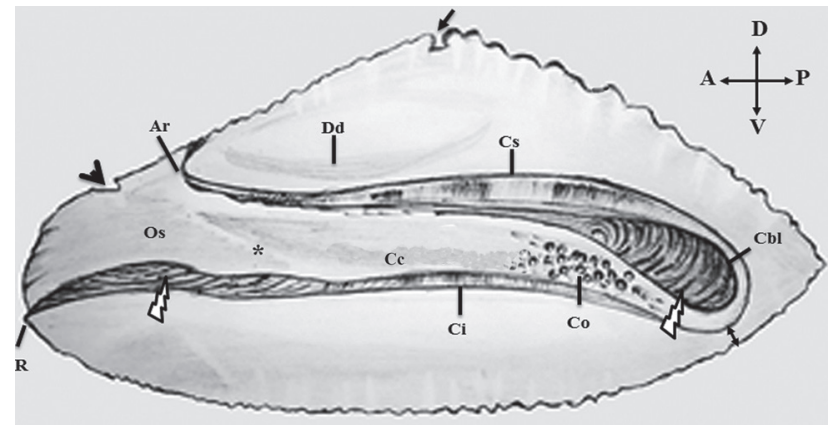

Figure 1. Schematic diagram of a typical sagitta (right) showing various characteristics on the medial surface of Eleutheronema tetradactylum. Abbreviation here and in Fig. 2: A, anterior side; Ar, antirostrum; Cbl, caudal bulb; Cc, caudal colliculum; Ci, crista inferior; $C$, concretion; $C S$, crista superior; D, dorsal side; Dd, dorsal depression; 0 s, ostium; P, posterior side; $R$, rostrum; $V$, ventral side; zigzag arrow, growth stripes; arrow head, excisura major; arrow, mid-dorsal groove; double arrow, width between posterior caudal end and the postero-ventral margin, asterisk, ' $V$ '-shaped ridge at the junction of ostium and cauda. that of the rostrum (Figs. 1, 2A-D, Tables 1-2). A distinct gap is developed between the rostrum and the antirostrum, termed as excisura major (Figs. 1, 2A-D, Tables 1-2).

\section{The margins and surface sculptures}

The sagitta is dorsally oval-shaped with a distinct irregular margin and is ventrally slightly curved with sinuate margin (Figs. 1, 2A-D). A distinct groove is developed near the mid-dorsal region of the dorsal margin and is termed as the mid-dorsal groove (Figs. 1, 2B-D). The mid-dorsal groove comprises a broad base and a tiny outer opening (Figs. 2B-D, Table 1). Several growth stripes are distinct in the various portions of the caudal end and the ventral wall of the ostium (Figs. 2A-D). The ridge-like cristae are well-developed on both side of the sulcus (Figs. 1, 2A-D). The caudal colliculum is present and including several small, globular concretions, whereas the ostial colliculum is absent (Figs. 1, 2A-D). A well-developed dorsal depression is observed on the medial surface of sagittae, while ventral depression is absent (Figs. 1, 2A-D).

\section{Variations of the sagitta morphologies in different size groups}

Eleutheronema tetradactylum showed many developmental variations of different sagittae components with-
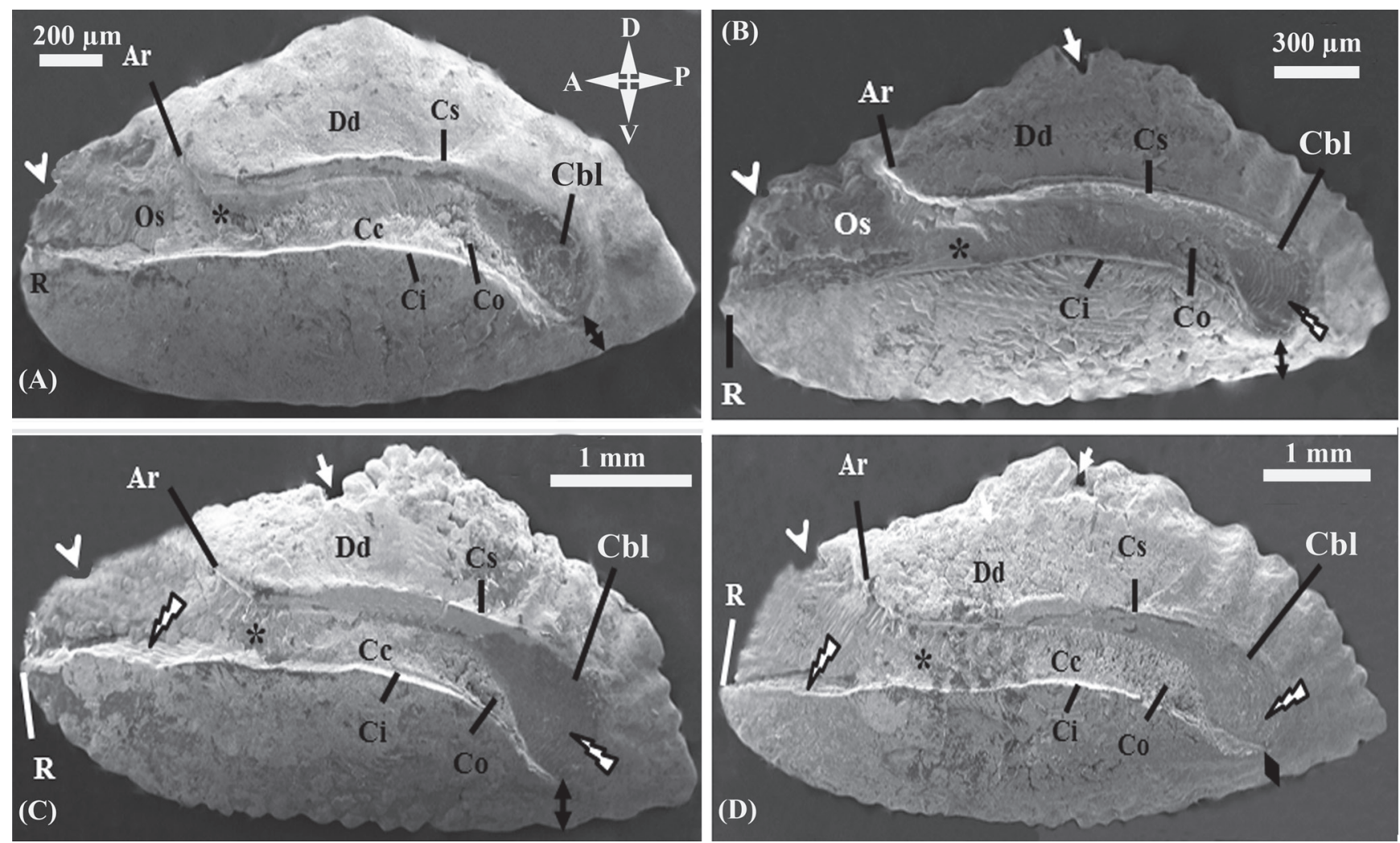

Figure 2. Scanning electron micrographs (SEM) of the medial surface of right sagittae of Eleutheronema tetradactylum: (A) Gr-I, smooth outer margin; (B) Gr-II, pointed antirostrum, deep dorsal depression and bent caudal end with growth stripes, the caudal colliculum includes numerous buttons like concretions, mid-dorsal groove (white arrow); (C) Gr-III, developed rostrum \& blunt antirostrum, growth stripes on the ventral wall of sulcus, shallow dorsal depression; (C) Gr-IV, blunt antirostrum, bent caudal end, reduced dorsal depression, granular caudal colliculum. 
Table 1. Relative features of the sagitta characteristics of the four fork length groups of Eleutheronema tetradactylum.

\begin{tabular}{|c|c|c|c|c|}
\hline Sagitta Characteristics & $\mathrm{Gr}-\mathrm{I}(11-12 \mathrm{~cm})(n=25)$ & Gr- II $(15-16 \mathrm{~cm})(n=45)$ & Gr- III $(19-20 \mathrm{~cm})(n=35)$ & Gr- IV $(23-24 \mathrm{~cm})(n=20)$ \\
\hline Rostrum & Poorly developed & III-developed & Developed & Well-developed \\
\hline Antirostrum & Indistinct & Developed, pointed & Developed, blunt & Reduced \\
\hline Outer margin & $\begin{array}{l}\text { Mostly smooth with very few indistinct } \\
\text { indentations }\end{array}$ & $\begin{array}{l}\text { Dorsally irregular, ventrally sinuate, } \\
\text { much distinct indentations }\end{array}$ & $\begin{array}{l}\text { Dorsally irregular, ventrally sinuate, } \\
\text { distinct some indentations }\end{array}$ & $\begin{array}{l}\text { Dorsally irregular, ventrally sinuate, } \\
\text { distinct some indentations }\end{array}$ \\
\hline Groove on the mid dorsal margin & Absent & Typical V-shaped notch & Cylindrical with flat base & Flask-shaped notch \\
\hline Sulcus & $\begin{array}{l}\text { Straight, slightly curved to caudal end. } \\
\text { Contains indistinct growth strips. }\end{array}$ & $\begin{array}{l}\text { Straight, comparatively more curved to } \\
\text { caudal end. Contains distinct growth } \\
\text { strips. }\end{array}$ & $\begin{array}{l}\text { Straight, bent near caudal end. } \\
\text { Contains distinct growth strips. }\end{array}$ & $\begin{array}{l}\text { Straight, bent near caudal end. } \\
\text { Contains distinct growth strips. }\end{array}$ \\
\hline $\begin{array}{l}\text { V-shaped impression at the junction of } \\
\text { ostium and cauda }\end{array}$ & Indistinct & Developed & Developed & Well-developed \\
\hline 0stium & $\begin{array}{l}\text { Well developed, vase-shaped, almost } \\
\text { smooth surface }\end{array}$ & $\begin{array}{l}\text { Well developed, wider anteriorly, vase- } \\
\text { shaped, rough surface with indistinct } \\
\text { growth stripes }\end{array}$ & $\begin{array}{l}\text { Well developed, wider, vase-shaped, } \\
\text { rough surface with some distinct } \\
\text { growth stripes }\end{array}$ & $\begin{array}{l}\text { Well developed, wider, vase-shaped, } \\
\text { mostly smooth surface with very few } \\
\text { growth stripes }\end{array}$ \\
\hline Cauda & Almost cylindrical posteriorly & $\begin{array}{l}\text { Posteriorly bulb-shaped with } \\
\text { prominent growth stripes }\end{array}$ & $\begin{array}{l}\text { Posteriorly bulb-shaped with } \\
\text { prominent growth stripes }\end{array}$ & $\begin{array}{l}\text { Posteriorly hockey stick like, indistinct } \\
\text { growth stripes }\end{array}$ \\
\hline Caudal colliculum & $\begin{array}{l}\text { Elongated, decorated with scattered } \\
\text { button like structures }\end{array}$ & $\begin{array}{l}\text { Elongated, decorated with scattered } \\
\text { and distinct small globular concretion }\end{array}$ & $\begin{array}{l}\text { Present, the concretion restricted near } \\
\text { posterior end }\end{array}$ & $\begin{array}{l}\text { Present, including fine granular } \\
\text { sculptures }\end{array}$ \\
\hline Dorsal depression & Shallow & Deep, wider & Shallow & Reduced \\
\hline Posterior end & Smooth, pointed, single lobed & $\begin{array}{l}\text { Smooth, blunt, crown shaped with } \\
\text { three lobes }\end{array}$ & Smooth, blunt, single lobed & $\begin{array}{l}\text { Smooth, pointed, crown shaped with } \\
\text { three lobes }\end{array}$ \\
\hline
\end{tabular}

Table 2. The morphometry (mean value \pm SD) of sagitta constituents of the four fork length groups of Eleutheronema tetradactylum.

\begin{tabular}{|c|c|c|c|c|}
\hline Sagitta features & $\mathrm{Gr}-\mathrm{I}(n=25)$ & Gr- II $(n=45)$ & Gr- III $(n=35)$ & Gr-IV $(n=20)$ \\
\hline Sagitta length (mm) & $4.31 \pm 0.58^{c}$ & $5.14 \pm 0.63^{b, c}$ & $5.72 \pm 0.71^{\mathrm{a}, \mathrm{b}}$ & $6.48 \pm 0.58^{\mathrm{a}}$ \\
\hline Sagitta width (mm) & $2.01 \pm 0.26^{\mathrm{a}}$ & $2.50 \pm 0.32^{\mathrm{a}}$ & $2.51 \pm 0.42^{\mathrm{a}}$ & $2.64 \pm 0.43^{\mathrm{a}}$ \\
\hline Sagitta weight (mg) & $3 \pm 0.39 c$ & $6 \pm 0.43^{b}$ & $8 \pm 0.43^{a}$ & $8 \pm 0.66^{a}$ \\
\hline Rostrum length $(\mu \mathrm{m})$ & $0.29 \pm 0.05^{\mathrm{a}}$ & $0.34 \pm 0.04^{\mathrm{a}}$ & $0.19 \pm 0.05^{b}$ & $0.27 \pm 0.03^{\mathrm{a}}$ \\
\hline Antirostrum length $(\mu \mathrm{m})$ & $0.13 \pm 0.05^{b}$ & $0.20 \pm 0.04^{a}$ & $0.22 \pm 0.02^{\mathrm{a}}$ & $0.11 \pm 0.55^{b}$ \\
\hline Sulcus length $(\mu \mathrm{m})$ & $2.89 \pm 0.02^{b}$ & $3.1 \pm 0.01^{\mathrm{a}}$ & $2.91 \pm 0.02^{b}$ & $2.72 \pm 0.03^{b}$ \\
\hline Sulcus width ( $\mu \mathrm{m})$ & $0.35 \pm 0.02^{\mathrm{a}}$ & $0.32 \pm 0.02^{\mathrm{a}, \mathrm{b}}$ & $0.31 \pm 0.02^{b}$ & $0.30 \pm 0.01^{b}$ \\
\hline Sulcus depth ( $\mu \mathrm{m})$ & $0.07 \pm 0.01^{b}$ & $0.10 \pm 0.01^{b}$ & $0.10 \pm 0.02^{\mathrm{a}}$ & $0.10 \pm 0.02^{\mathrm{a}}$ \\
\hline Width of excisura major $(\mu \mathrm{m})$ & $0.75 \pm 0.01^{d}$ & $0.10 \pm 0.01^{\mathrm{a}}$ & $0.97 \pm 0.01^{b}$ & $0.81 \pm 0.01^{c}$ \\
\hline ostium length $(\mu \mathrm{m})$ & $0.67 \pm 0.01^{c}$ & $0.9 \pm 0.02^{a}$ & $0.88 \pm 0.02^{b}$ & $0.66 \pm 0.01 c$ \\
\hline Ostium width $(\mu \mathrm{m})$ & $0.38 \pm 0.04^{b}$ & $0.6 \pm 0.01^{a}$ & $0.38 \pm 0.01^{b}$ & $0.53 \pm 0.01^{\mathrm{a}}$ \\
\hline Cauda length $(\mu \mathrm{m})$ & $2.19 \pm 0.02^{\mathrm{a}}$ & $2.2 \pm 0.02^{b}$ & $2.03 \pm 0.02^{d}$ & $2.00 \pm 0.02^{c}$ \\
\hline Cauda width $(\mu \mathrm{m})$ & $0.35 \pm 0.01^{\mathrm{a}}$ & $0.30 \pm 0.01^{c}$ & $0.33 \pm 0.01^{b}$ & $0.31 \pm 0.01^{c}$ \\
\hline Length of caudal bulb ( $\mu \mathrm{m})$ & $0.45 \pm 0.02^{\mathrm{d}}$ & $0.60 \pm 0.02^{c}$ & $0.70 \pm 0.02^{b}$ & $1.29 \pm 0.02^{\mathrm{a}}$ \\
\hline Width of the groove of mid dorsal margin $(\mu \mathrm{m})$ & $*$ & $21.89 \pm 1.2^{\mathrm{a}}$ & $18.03 \pm 1.52^{b}$ & $4.33 \pm 0.72^{c}$ \\
\hline Depth of the groove of mid dorsal margin $(\mu \mathrm{m})$ & * & $18.47 \pm 0.61^{\mathrm{a}}$ & $10.58 \pm 1.2^{b}$ & $14.09 \pm 1.28 c$ \\
\hline Width between posterior caudal end and the postero-ventral margin ( $\mu \mathrm{m})$ & $0.13 \pm 0.01^{\mathrm{a}, \mathrm{b}}$ & $0.10 \pm 0.01^{b, c}$ & $0.14 \pm 0.01^{\text {a }}$ & $0.11 \pm 0.01^{c}$ \\
\hline Width of crista superior-dorsal margin ( $\mu \mathrm{m})$ & $0.52 \pm 0.05^{b}$ & $0.60 \pm 0.01^{\mathrm{a}}$ & $0.56 \pm 0.01^{\mathrm{a}, \mathrm{b}}$ & $0.54 \pm 0.01^{b}$ \\
\hline Width of crista inferior-ventral margin $(\mu \mathrm{m})$ & $0.59 \pm 0.02^{b}$ & $0.70 \pm 0.02^{\mathrm{a}}$ & $0.61 \pm 0.02^{b}$ & $0.52 \pm 0.03 c$ \\
\hline
\end{tabular}

* Lack of the structures in the group. The same letters after the mean values mean the absence of significant differences between the groups.

in body size groups (Figs. 2A-D; Tables 1-2). The sagitta length and width vary accordingly with the four body size groups, while the sagitta weight remains the same after certain growth of body size (Fig. 3). In the study, based on the body size, the fishes in group IV (Gr-IV) are comparatively older (mature male) and those in group I (Gr- I) is relatively younger (younger male) among the four studied groups. All the studied sagitta components except the otolith width, rostrum length, antirostrum length, sulcus length and the width of crista superior-dorsal margin show a significant difference between these two groups (Table 2). Furthermore, some of the sagitta constituents such as the caudal length $(\mathrm{Cl}$, Fig. $4 \mathrm{~A})$, length of caudal bulb (Cbl, Fig. 4B), width of crista inferior-ventral margin (CriV, Fig. 4C), sulcus width (SW, Fig. 4D), and sulcus depth (SD, Fig. 4E) show a relative developmental variation in the four different body size groups (Table 2 ). The normality test shows that all the studied sagitta features are normally distributed in the four body size groups (Table 3). The ANOVA test with the morphometric data revealed that there are significant developmental variations of different sagittae components among the four body size groups (Figs. 2A-D; 5A-F, 6A-F, 7A-D, 8A-C ; Tables 1-2).

The development of the rostrum and antirostrum are relatively different among the four body size groups (Figs. 2A-B, 6A-B; Table 2). The growth stripes in different parts of the sulcus are prominent in the groups with larger specimens (Table 1). It is observed that the margins and marginal sculpture of the sagittae are var- 


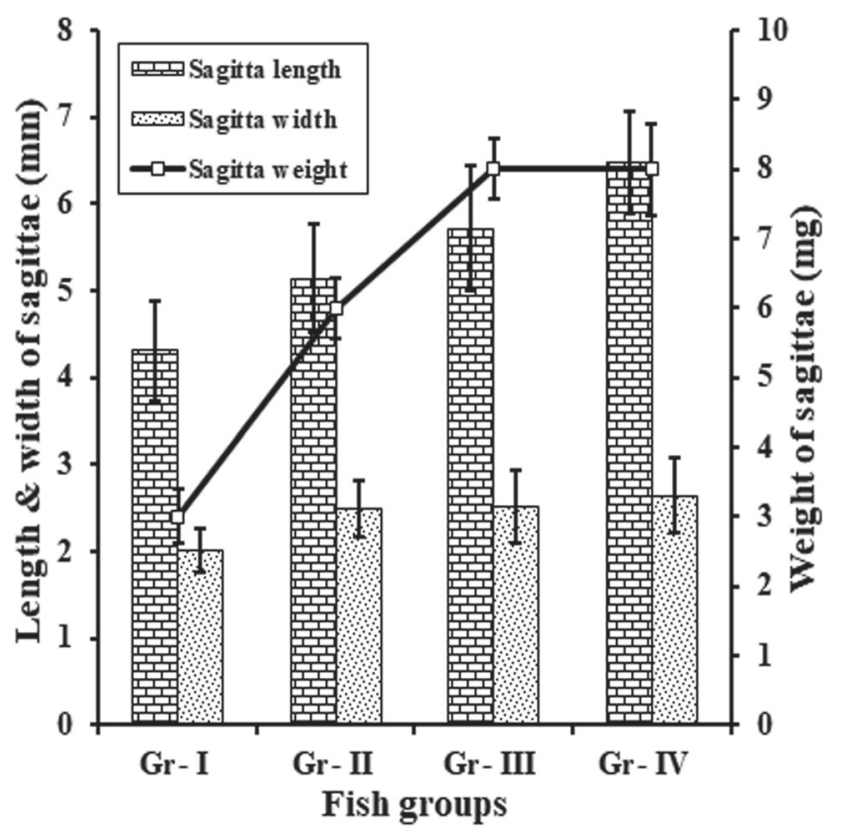

Figure 3. Comparative relationships between sagitta length, width and weight and fork length in the four groups of Eleutheronema tetradactylum. Here and in Fig. 4: group I (Gr-I) - 11-12 cm FL, group II (Gr-II) - 15-16 cm FL, group III (Gr-III) - 19-20 cm FL, group IV (Gr-IV) - 23-24 cm FL.

ied with the increment of the total body length of fishes (Figs. 2A-D; Table 1). The outer margins (i.e., dorsal and ventral margins) and their marginal sculptures (i.e., smooth margin, irregular margin, etc.) of the sagittae are varied with the increment of the total body length of the fishes (Figs. A-D; Table 1). The dorsal margin of the sagitta in the individuals in group I is mostly smooth while it is developed as characteristically irregular in the groups of the larger specimen (Figs. 2A-D; Table 1). The ventral margin of the sagitta in the groups (i.e., Gr-II, Gr-III, and Gr-IV) with larger specimens are the sinuate type with very distinct several marginal indentations which are very indistinct and few in the sagitta of the individuals in group I (Figs. 2A-D; Table 1). The groove on the mid-dorsal mar-

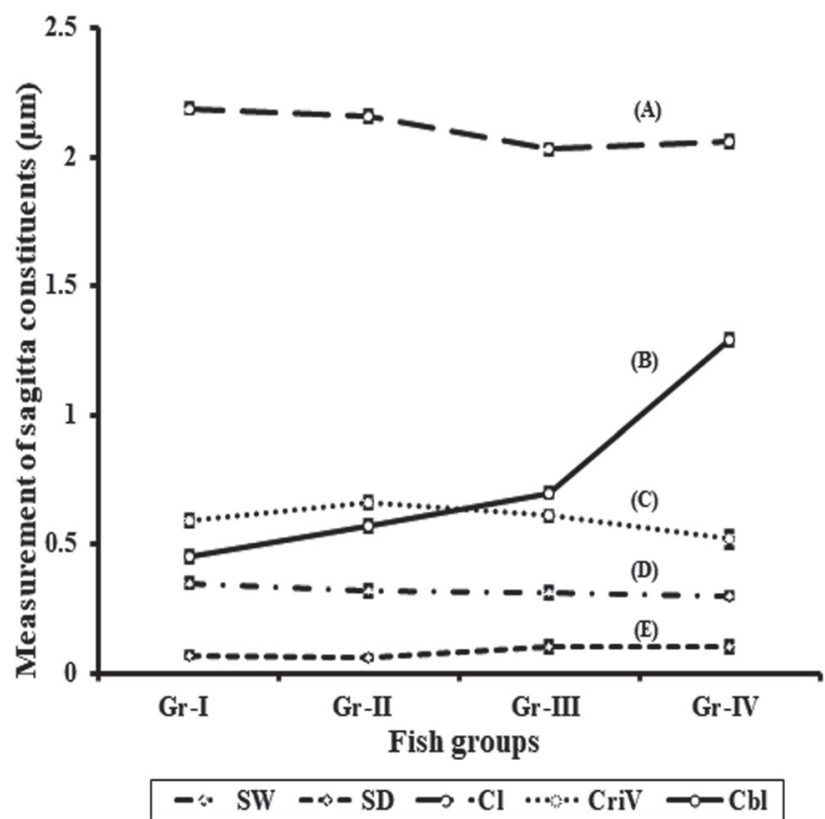

Figure 4. Relationships between the body size groups with some sagitta constituents of Eleutheronema tetradactylum: (A) caudal length (Cl), (B) Length of caudal bulb (Cbl), (C) width of crista inferior-ventral margin (CriV), (D) Sulcus width (SW); (E) sulcus depth (SD).

gin of sagittae is absent in group (Gr-l) with smaller specimens while it is characteristically very distinct with various shapes and sizes in groups (Gr-II, Gr-III, and Gr-IV) with larger specimens (Tables 1-2). A ' $V$ '-shaped ridge is developed near the junction of ostium and cauda in the sulcus and is well-developed in groups with larger specimens (Asterisk, Figs. 2A-D; Table 1). Development of the caudal bulb $(\mathrm{Cbl})$ at the caudal end is significantly and positively correlated to the increment of the total body length (Figs. 2A-D, 7B; Tables 1-2). The caudal bulb is measured of $1.29 \pm 0.02 \mu \mathrm{m}$ in length in the individuals in group IV (Gr-IV; 23-24 cm FL) (Fig. 2D) and $0.45 \pm 0.02 \mu \mathrm{m}$ in length in the specimens in group I (Gr-l; $11-12 \mathrm{~cm} \mathrm{FL)}$ (Figs. 2A, D; Table 2). The development of the sagitta

Table 3. The tabular representation of the $p$-value of all corresponding sagitta constituents of the normality test (Shapiro-Wilk test). Individual $p$-value is greater the alpha value (0.05). All the variables are normally distributed in all the groups of Eleutheronema tetradactylum.

\begin{tabular}{lcccc}
\hline & Sagitta features & Gr-II & Gr-III & Gr-IV \\
\hline Sagitta length (OL) & 0.1109 & 0.9789 & 0.8203 & 0.1568 \\
Sagitta width (OW) & 0.9999 & 0.5031 & 0.4604 & 0.0834 \\
Sagitta weight (Owt) & 0.5298 & 0.9370 & 0.9370 & 0.5043 \\
Sulcus length (SL) & 0.7560 & 0.8294 & 0.8151 & 0.9585 \\
Sulcus width (SW) & 0.7495 & 0.7475 & 0.3928 & 0.2182 \\
Sulcus depth (SD) & 0.3271 & 0.7431 & 0.5836 & 0.5157 \\
Rostrum length (RL) & 0.5974 & 0.7979 & 0.2717 & 0.9620 \\
Antirostrum length (ArL) & 0.2908 & 0.2562 & 0.8433 & 0.1350 \\
Width of excisura major (EXW) & 0.4184 & 0.5459 & 0.3080 & 0.8703 \\
ostium length (OSI) & 0.6848 & 0.6350 & 0.3193 & 0.4152 \\
Ostium width (Osw) & 0.7883 & 0.7413 & 0.6966 & 0.2200 \\
Cauda length (Cl) & 0.6471 & 0.6286 & 0.6436 & 0.7450 \\
Cauda width (CW) & 0.9874 & 0.8120 & 0.4275 & 0.6759 \\
Length of caudal bulb (Cbl) & 0.9882 & 0.2584 & 0.1071 & 0.3785 \\
Width between posterior caudal end and the postero-ventral margin (CPVM) & 0.8648 & 0.0707 & 0.4367 & 0.2636 \\
Width of crista superior-dorsal margin (CrsD) & 0.1735 & 0.8698 & 0.1961 & 0.5733 \\
Width of crista inferior-ventral margin (CriV) & 0.9903 & 0.9223 & 0.3159 \\
\hline
\end{tabular}




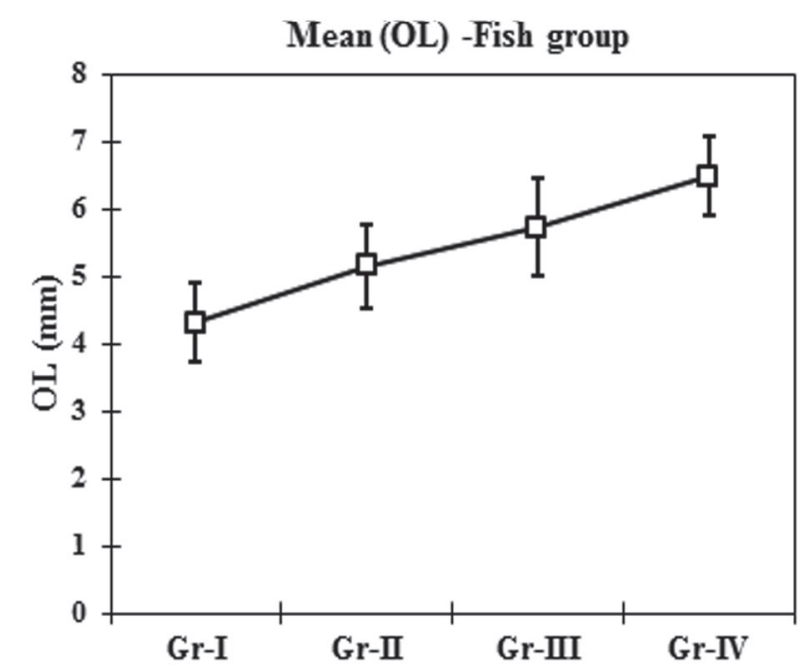

(A)

Fish groups

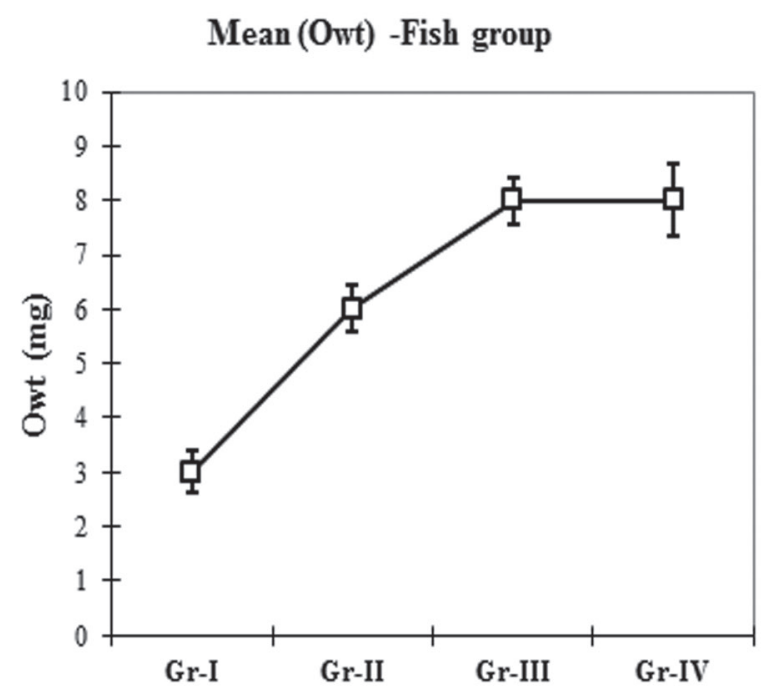

(C)

Fish group

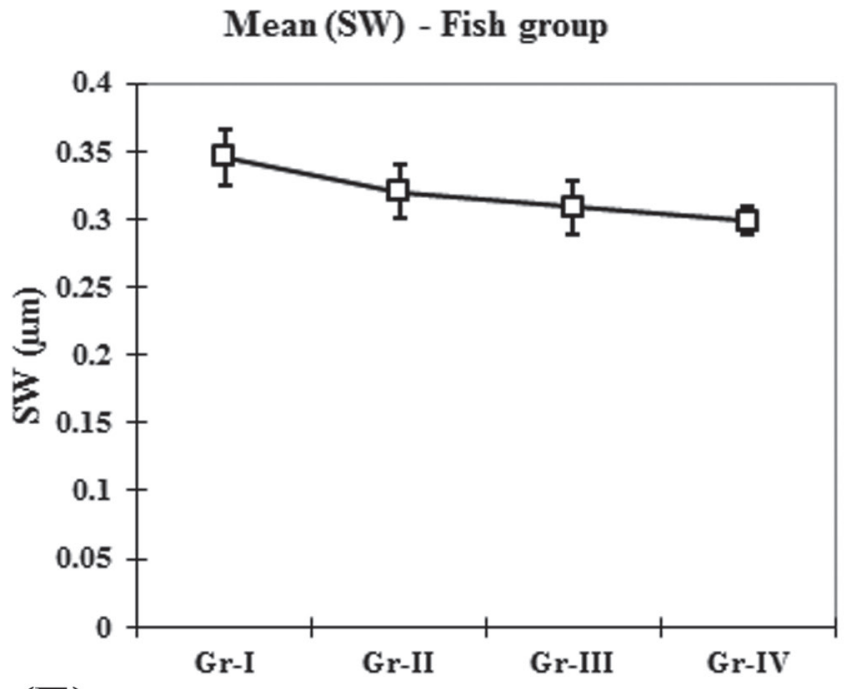

(E)

Fish group

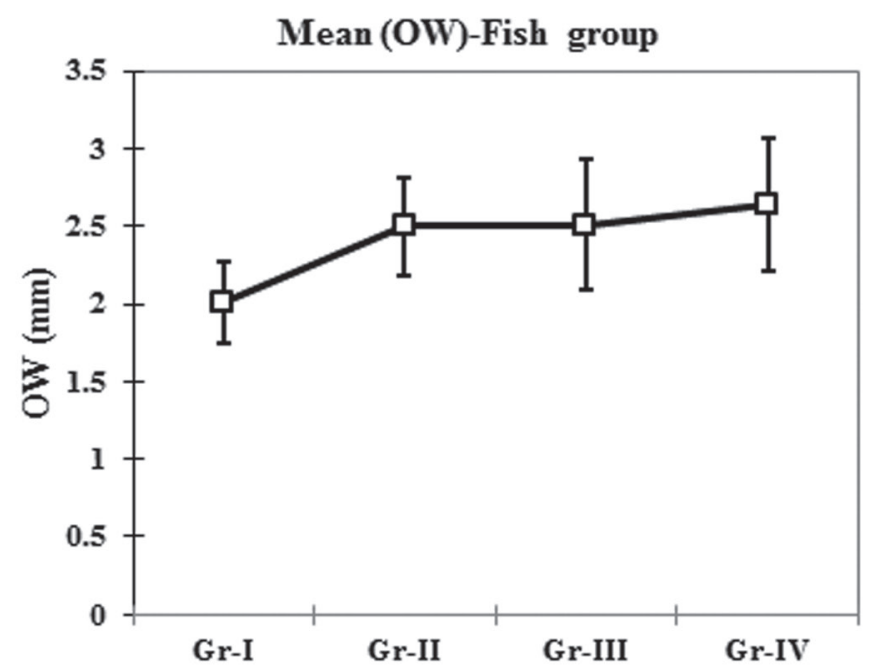

(B)

Fish group

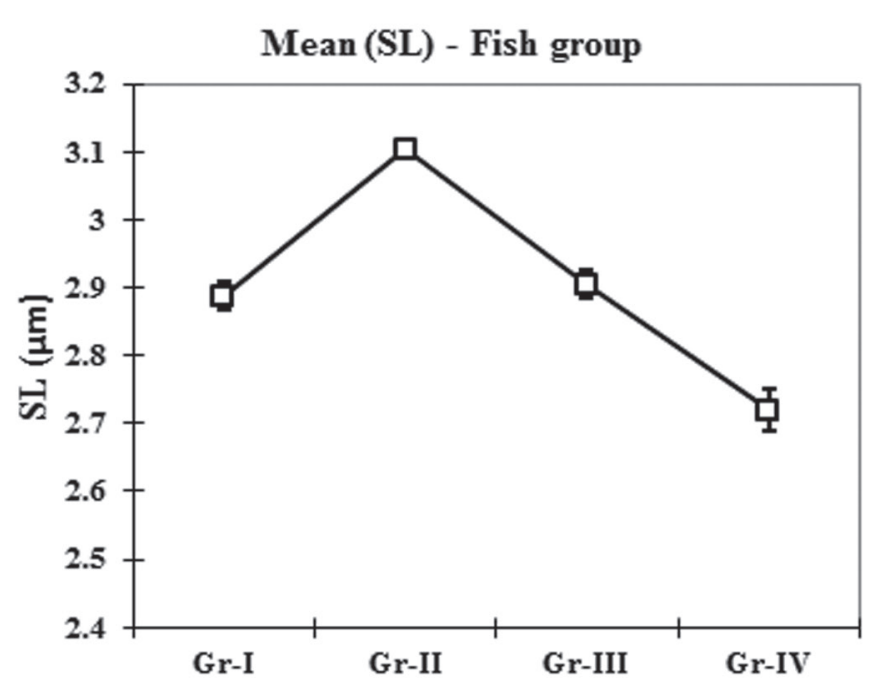

(D)

Fish group

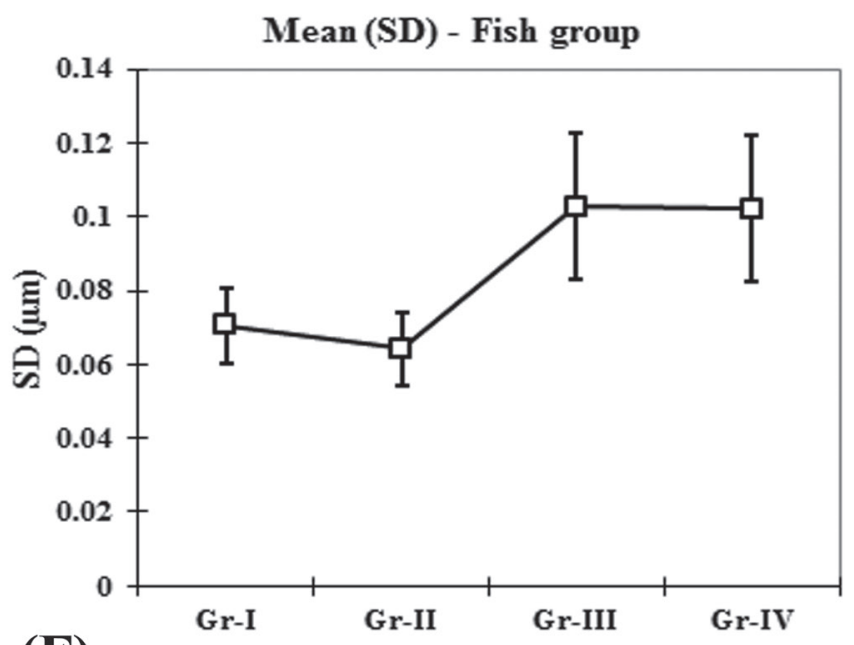

(F)

Fish group

Figure 5. Relationships of the body size groups with different sagitta features: (A) sagitta length (OL); (B) sagitta width (OW); (C) sagitta weight (Owt); (D) sulcus length (SL); (E) sulcus width (SW); (F) sulcus depth (SD). 


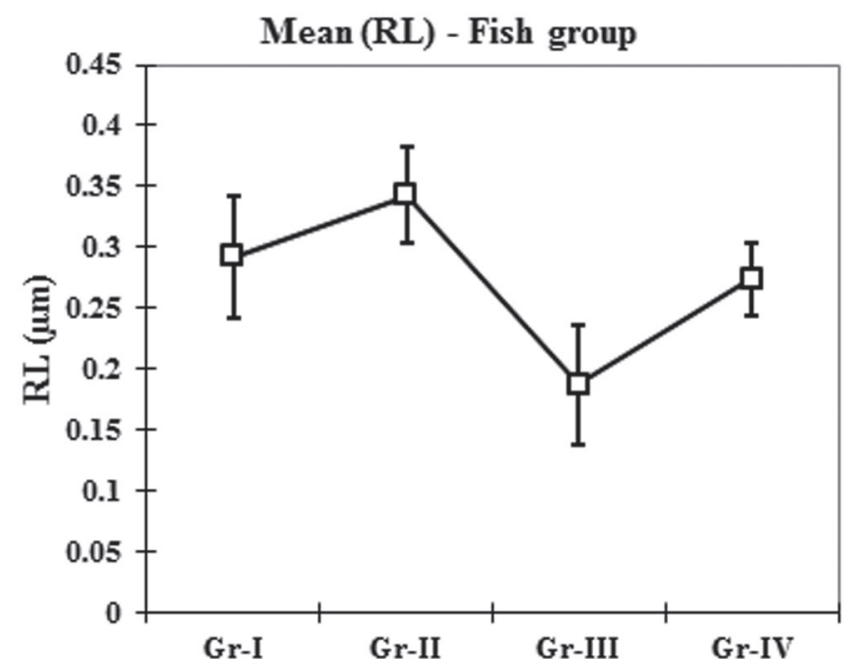

(A)

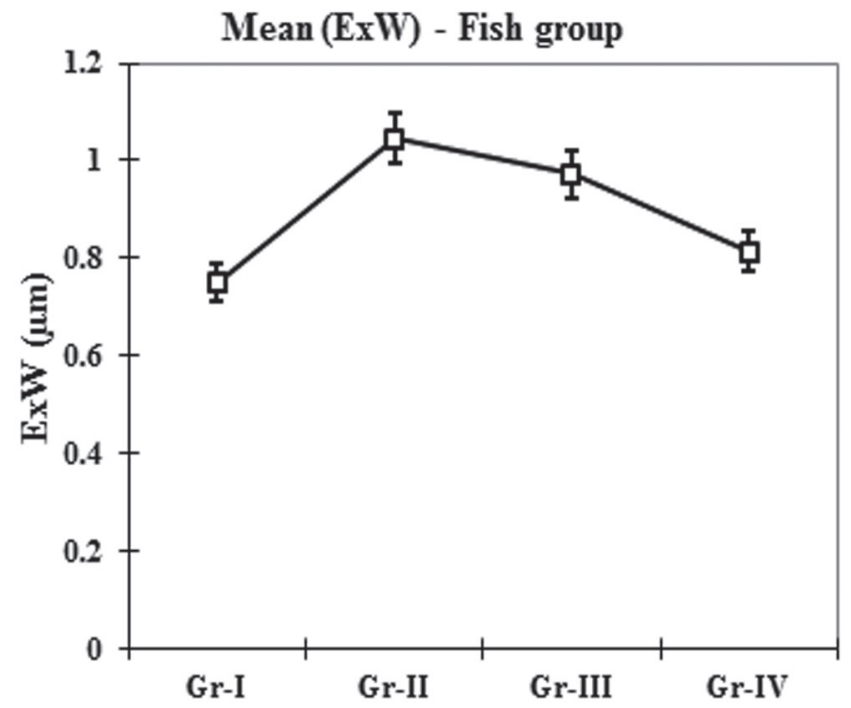

(C)

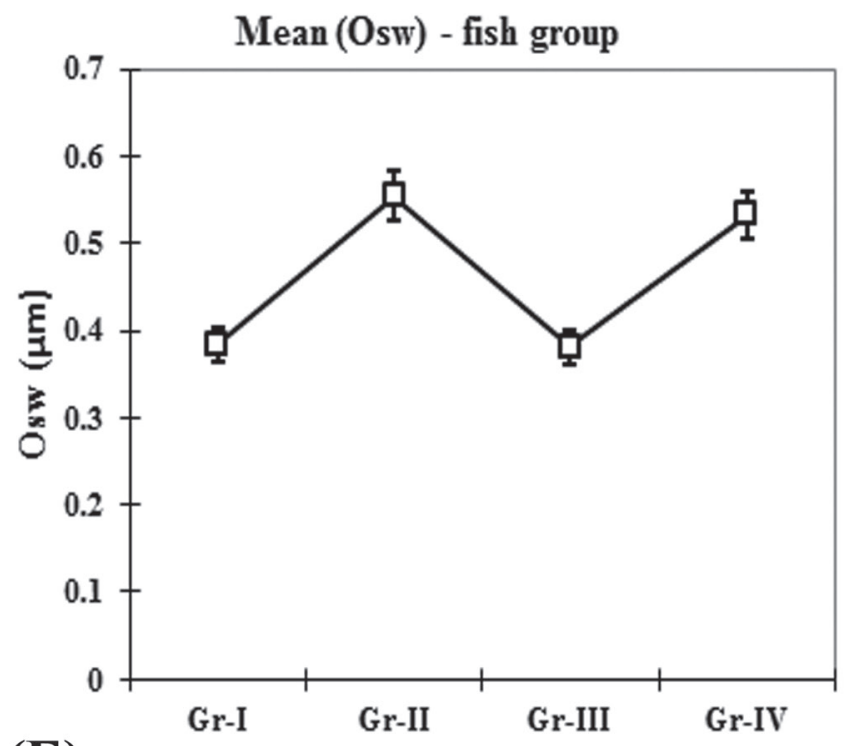

(E)

Fish group

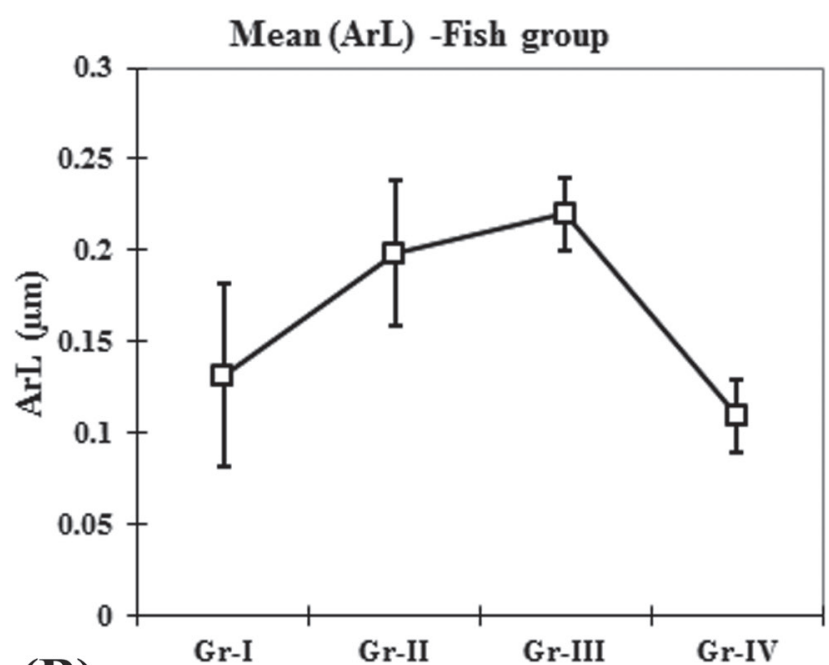

(B)

Fish group

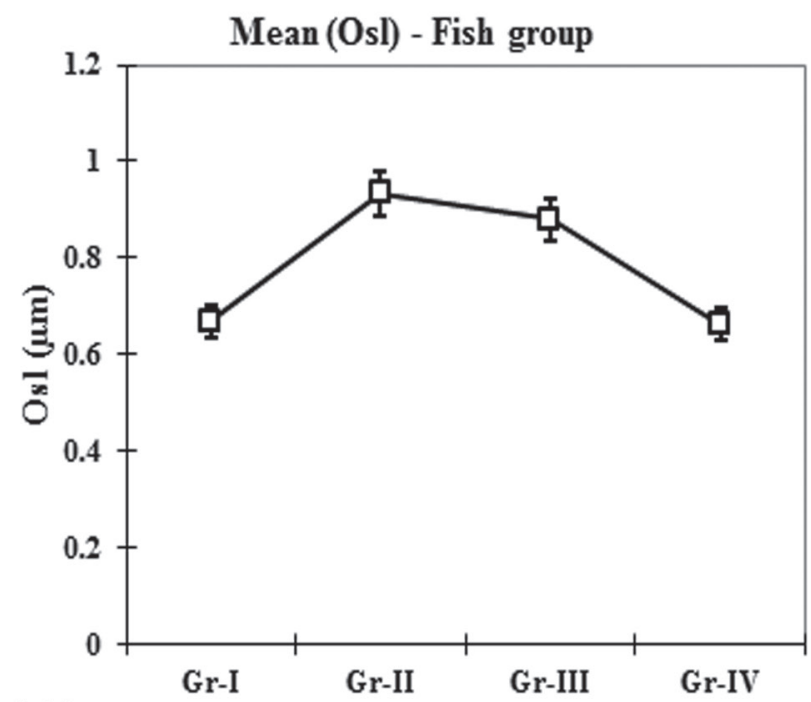

(D)

Fish group

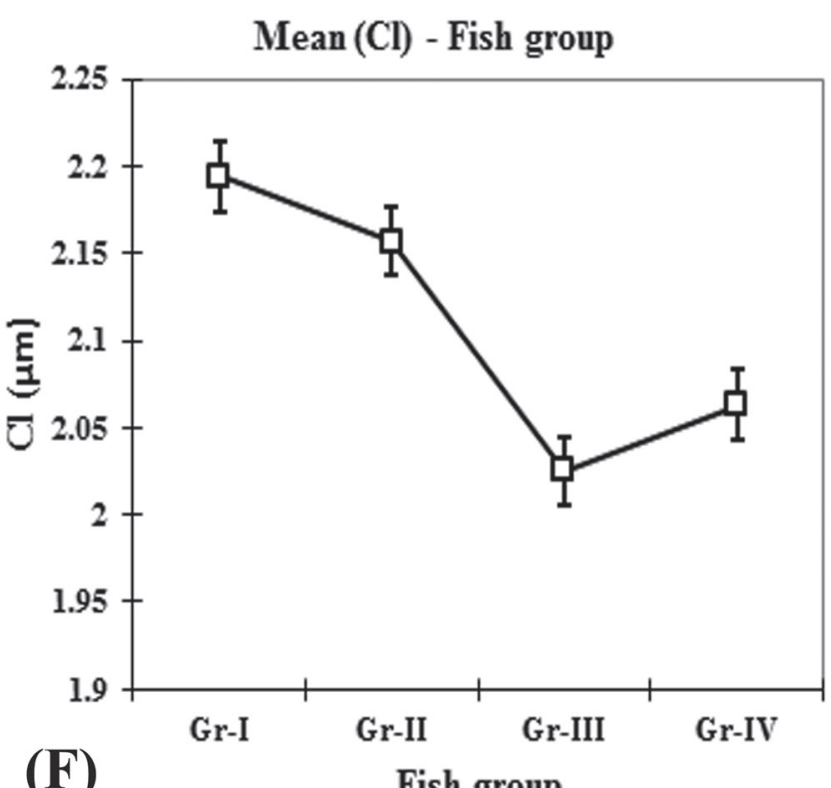

Fish group

Figure 6. Relationships of the body size groups with different sagitta constituents: (A) rostrum length (RL); $(B)$ antirostrum length (ArL); $(C)$ width of excisura major (ExW); (D) ostium length (OL); (E) ostium width (OW); (F) cauda length (Cl). 

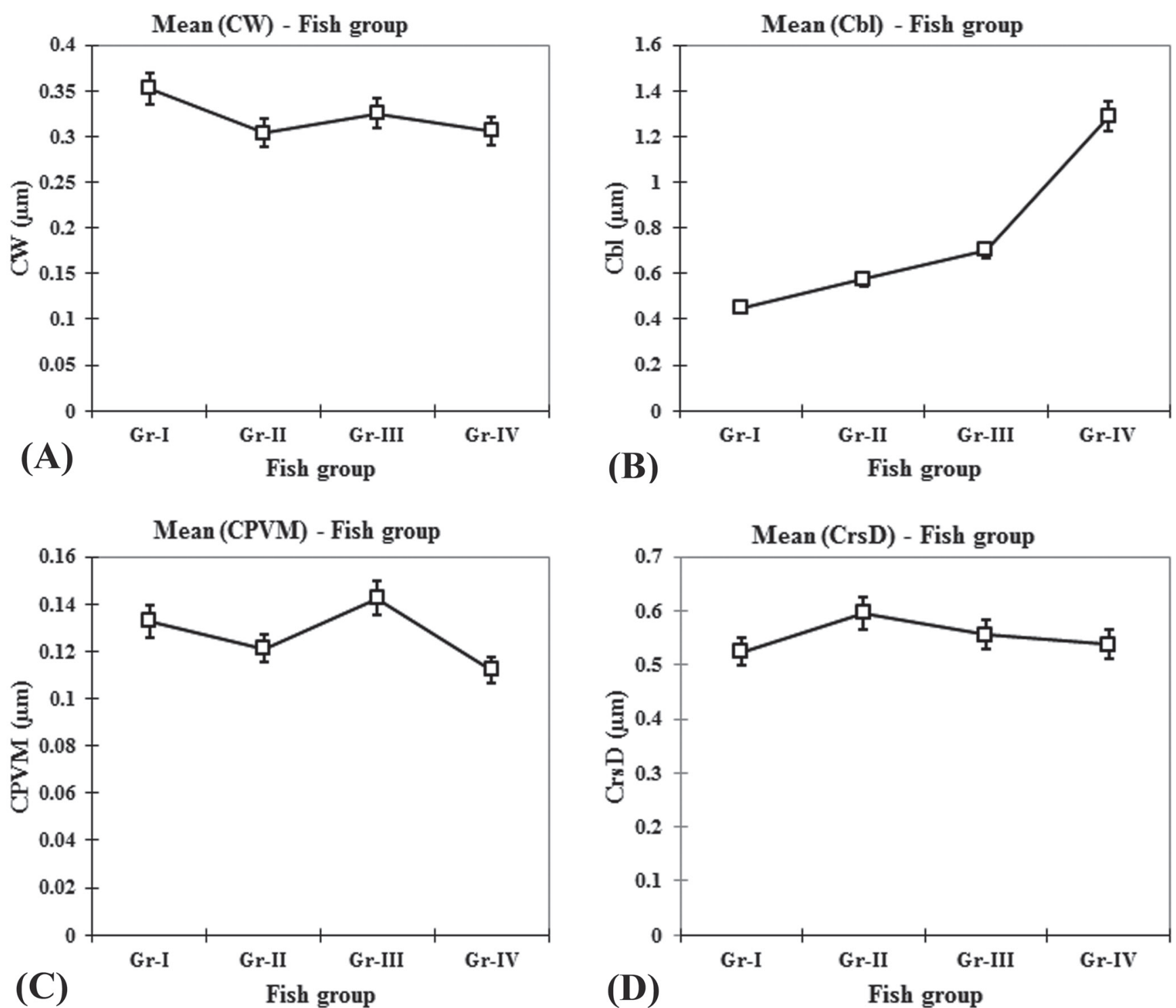

Figure 7. Relationships of the body size groups with different sagitta constituents: (A) cauda width (CW); (B) length of caudal bulb (Cbl); (C) width between posterior caudal end and the postero-ventral margin (CPVM); (D) width between dorsal margin to crista superior (CrsD).

length is significantly increased with the growth of total body length of fishes (Figs. 3, 5A; Table 2). The sagitta width is slightly increased with the growth of total body length and their developmental relationship is not significant (Fig. 5B; Table 2). The sagitta weight is initially increased with the increment of the total body length and after a certain body size (19-20 cm FL), its development remains the same or insignificantly developed as body length increases (Figs. 2A-D, 3, 5C; Tables 1-2). The development of the caudal length $(C l)$ and sulcus width (SW) is negatively correlated to the total body length (Figs. 4, 5E, 6F; Table 2). The sulcus depth (SD) and the width of the crista inferior to the ventral margin (CriV) are larger in groups with smaller individuals than those in groups with larger individuals (Figs. 2A-D, 4, 5E, 8A; Table 2).

In the present study, it is observed that the sagitta morphologies of male E. tetradactylum have several relative relationships in respect of hermaphroditism with another protandrous Polynemidae fish (Polydactylus virginicus) and three protandrous Sparidae fishes (Sparidentex hasta, Acanthopagrus berda, and Acanthopagrus latus) irrespective of their male/female discriminations (Table 4). This comparative study showed that the sagitta morphologies are closely similar, but with some significant species-specific differences within the Polynemidae fishes while they are characteristically different among the species of other protandrous Perciformes fishes (Table 4). The morphostructural and morphometric analysis advocates that the growth of the sagitta length and caudal bulb length are significantly increased with the increment of the total body length than that of the sagitta width and weight (Figs. 3, 5A-C, 7B; Table 2). The sagitta length, weight, and caudal bulb length may be used as important predictors to evaluate the body size of E. tetradactylum.

\section{DISCUSSION}

The detailed morphostructural characteristics of the medial surface of the sagittae of the male E. tetradacty- 

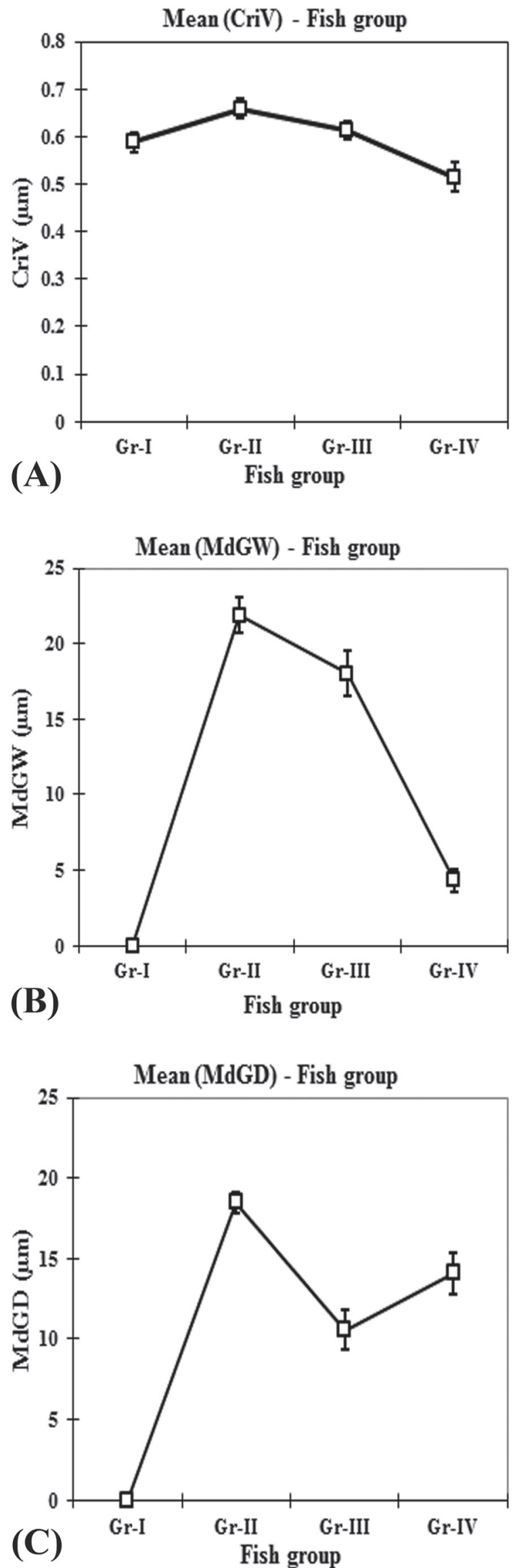

Figure 8. Relationships of the body size groups with the different sagitta constituents: (A) width between ventral margin to crista inferior (CriV); (B) width of the groove of mid dorsal margin (MdGW); (C) depth of the groove of mid dorsal margin (MdGD). lum (Polynemidae: Perciformes) in different body size groups are described for the first time using scanning electron microscopy. The development of the sagitta constituents varies in different stages of the sexual maturity of the male E. tetradactylum. This kind of developmental differences in different body size groups are also reported in other Perciformes fishes; i.e., Chlorurus sordidus (Jawad et al., 2018), Anabas testudineus (Bardhan et al., 2021), Umbrina cirrose (Başusta \& Khan, 2021). The characteristics of various sagitta constituents of E. tetradactylum slightly differ from those of the other Polynemidae fish (e.g., Polydactylus virginicus, Santificetur et al., 2017) and considerably differ from other protandrous marine Peciformes fishes (e.g., Sparidentex hasta, Acanthopagrus berda, and Acanthopagrus latus; Abdulsamad, 2017) (Table 4). The sagitta of E. tetradactylum is a spindle-shaped structure, however this varies with the protandrous Polydactylus virginicus and the three protandrous Sparidae fishes (Table 4). The medial surface of the sagitta comprises a well-developed sulcus groove as also reported in other fishes (Dehghani et al., 2016; Omar \& Moselhy, 2016; Abdulsamad, 2017; Jawad et al., 2018; Khedher \& Fatnassi, 2018), and this groove may assist for connecting the medial surface with the sensory cells of the internal ears (Popper \& Hoxter, 1981; Popper \& Lu, 2000). A number of sulcus morphologies of $E$. tetradactylum are characteristically identical with another marine as well as freshwater Perciformes fishes (Smale et al., 1995; Bremm \& Schulz, 2014; Omar \& AMohamed, 2016; Omar \& Moselhy, 2016; Abdulsamad, 2017; Jawad et al., 2018; Bardhan et al., 2021). Hunt (1992) stated that the otolith morphologies between male and female fishes are almost the same, whereas several authors reported that there are some structural differences between these genders in many fish species (Vallisneri et al., 2008; Bostanci et al., 2012; Kontaş \& Bostanci, 2015). In the present study it is observed that the development of sagittal constituents varies also with different body size groups in a particular gender (e.g., male fish).

The development of the medial surface sagitta structures on of $E$. tetradactylum is characteristically variable among different body-size groups, as described in other fishes (Jawad et al., 2018; Bardhan et al., 2021). However, several sagitta features of E. tetradactylum and Polydactylus virginicus (Santificetur et al., 2017) are mostly similar (Table 4) and possibly the common identifying features of the sagitta in the Polynemidae species. In the present study, we show that the sagittae of the smaller fish group possess entire smooth surface and marginal sculpture, whereas those sagitta features considerably differ with the increase of the total body length, probably due to various pattern of the calcium carbonate crystals deposition (Campana \& Thorrold, 2001; Schwarzhans \& Grenfell, 2002; Volpedo \& Echevarria, 2003; Vilizzi, 2018; Pracheil et al., 2019).

It has been suggested that the increase of the otolith weight is significantly proportional to the total body length of the individuals in some fish groups but the length and width of the otolith are not (Gümüs \& Kurt, 2009; Bardhan et al., 2021). In the present study, the 
Table 4. Comparative characteristics of the sagitta morphologies of Eleutheronema tetradactylum with those of another Polynemidae fish and some other protandrous, hermaphrodite perciformes fishes in marine habitat.

\begin{tabular}{|c|c|c|c|c|c|}
\hline Family & Polyne & emidae & & Sparidae & \\
\hline Sagittal features & Eleutheronema tetradactylum & Polydactylus virginicus ${ }^{7}$ & Sparidentex hasta ${ }^{2}$ & Acanthopagrus berda ${ }^{2}$ & Acanthopagrus latus ${ }^{2}$ \\
\hline Shape & Spindle & Oblong & Oblong & Oval & Elliptical \\
\hline Anterior region & Flattened, round & Flattened, oblique-round & Flattened, round & Oblique, peaked-round & Flattened, peaked round \\
\hline Posterior region & Oblique, peaked-round & Oblique, peaked-round & Flattened, round & Flattened, round & Flattened, peaked round \\
\hline Sulcus morphology & Heterosulcoid & Heterosulcoid & Heterosulcoid & Heterosulcoid & Heterosulcoid \\
\hline Sulcus shape & Straight, posteriorly curved & Y-shaped, swollen posteriorly & Straight, posteriorly curved & Straight, posteriorly curved & Straight, posteriorly curved \\
\hline Sulcus type & Ostio-pseudocaudal & 0stio-pseudocaudal & Ostio-pseudocaudal & Ostio-pseudocaudal & Ostio-pseudocaudal \\
\hline Rostrum & Broad, pointed & Short, pointed & Indistinct & Elongated, blunt & Broad, blunt \\
\hline Antirostrum & Short, blunt & Broad, blunt & Indistinct & Pointed & Short, blunt \\
\hline Excisura major & Indistinct & Present & Absent & Present & Absent \\
\hline Excisura minor & Absent & Absent & Absent & Poorly developed & Developed \\
\hline Ostium & Flat, wider anteriorly & Funnel like, wider anteriorly & Flat, wider anteriorly & Flat with V-shaped notch anteriorly & Flat, narrow anteriorly \\
\hline Cauda & $\begin{array}{l}\text { Bent } 1 / 3 \text { part at ventral side, bulb- } \\
\text { shaped with prominent growth } \\
\text { stripes }\end{array}$ & $\begin{array}{l}\text { Bent } 1 / 3 \text { part at ventral side with } \\
\text { prominent growth stripes }\end{array}$ & $\begin{array}{l}\text { The bent part is comparatively } \\
\text { larger }\end{array}$ & Bent $1 / 3$ part at ventral side & Bent $1 / 3$ part at ventral side \\
\hline Growth stripe & Prominent in sulcus & Prominent in sulcus & Prominent in cauda & Indistinct & Indistinct \\
\hline Dorsal margin & Irregular & Lobed & Crenate & Sinuate & Irregular \\
\hline Ventral margin & Sinuate sculpture & Entire & Rounded & Rounded & Aciculate \\
\hline Surface sculpture & Absent & Absent & Present posteriorly & Absent & Absent \\
\hline Dorsal Depression & Wider, shallow & Absent & Absent & Absent & Present \\
\hline
\end{tabular}

* Based on published figures and descriptions of ${ }^{1}$ Santificetur et al., 2017; ${ }^{2}$ Abdulsamad, 2017.

weight of the sagitta in the E. tetradactylum is increased with the growth of total body length of the individuals in the young male groups with smaller body size (i.e., the sagitta weight in group I fishes is lesser than that in the group II), while this increment of the otolith weight is restricted in the mature male group with larger body size (i.e., the sagitta weight in the group III fishes is almost similar to that in the group IV). Furthermore, the morphometric measurements of the sagitta in E. tetradactylum reveal that the length of the otolith is significantly related to the total body length of the fishes instead of the otolith width and also reported in other fish families such as Nototheniidae (Lombarte et al., 1991), Merluccidae (Lombarte \& Lleonart, 1993); Labridae (Skeljo \& Ferri, 2012); Cyprinidae (Kontaş \& Bostanci, 2015), Sparidae (Khedher \& Fatnassi, 2018), Sciaenidae (Carvalho et al., 2020). It is assumed that the sagitta formation in fishes may be completed at a certain body length due to constant weight. Additionally, the development of the caudal bulb is directly proportional to the growth of total body length in the E. tetradactylum. It is presumed that the relationship between the total body length and various characteristics of the otolith may be varied with the fish species and their relative habitats (Jawad, 2007; Jawad et al., 2018; Khedher \& Fatnassi, 2018; Bardhan et al., 2021).

The sagitta features of the male E. tetradactylum shows some characteristic similarities with other marine perciformes fishes irrespective of their male/female gender specificity (Ballagh et al., 2012; Kontaş \& Bostanci, 2015; Avigliano et al., 2016; Omar \& AMohamed, 2016; Omar \& Moselhy, 2016; Santificetur et al., 2017; Abdulsamad, 2017; Khedher \& Fatnassi, 2018; Jawad et al., 2018). In the present study, sagitta characteristics of the male E. tetradactylum are described and may have some variations with those of the female individual but this requires further investigations. The results of the current study advocate that the sagitta features in different maturation phase of maleness of E. tetradactylum may be convenient for future studies of the otolith of other protandrous, hermaphrodite fishes and ultimately find out the relatedness among the species as well as male and female discriminations of the Polynemidae family in respect of systematics and gender choice respectively.

\section{ACKNOWLEDGMENTS}

The authors thank principal Prof. Mohua Das, subject coordinator Prof. Debarati Mukherjee, and all other faculty members of the Department of Zoology, Women's College Calcutta, Kolkata, West Bengal, India, for their help in this study. The authors are grateful to all members of SEM Unit, Zoological Survey of India (ZSI), Kolkata, for their help with the scanning electron microscopy studies. The authors are thankful to Dr. Amit Mukhopadhyay, Mollusca Section, Zoological Survey of India (ZSI), Kolkata, for his constructive suggestions in this work. The authors are also thankful to the Fish Division, Zoological Survey of India (ZSI), Kolkata, for the identification of the studied fish in this work. The authors are also grateful to the reviewers and editorial team of the manuscript for their constructive suggestions.

\section{AUTHORS' CONTRIBUTIONS}

S.R.: Design the work, dissection of first part of the otolith, guidance of dissection, SEM preparation and photography, arrangement and analysis of figures, illus- 
tration steps and microscopy, statistical analysis, graphical representations, and part of the description, supervision on the whole work, final revision of the whole manuscript. I.B.: Collection of the samples, dissection of the sagitta otolith from fish, schematic drawing of the otolith, SEM preparation, morphological and morphometry data collection, arrangement of text, table and references.

\section{CONFLICT OF INTEREST}

The authors declare that they have no conflict of interest.

\section{REFERENCES}

Abdulsamad, S.M.S. 2017. Comparison of some morphological characteristics of three sparid fishes (Perciformes: Sparidae) otoliths (Sagitta) from Shatt Al-Arab River, Basrah (southern Iraq). Mesopotamia Environmental Journal, 3: 33-40.

Avigliano, E.; Jawad, L.A. \& Volpedo, A.V. 2016. Assessment of the morphometry of saccular otoliths as a tool to identify triplefin species (Tripterygiidae). Journal of Marine Biological Association UK, 96(5): 1167-1180.

Ballagh, A.C.; Welch, D.J.; Newman, S.J.; Allsop, Q. \& Stapley, J.M. 2012. Stock structure of the blue threadfin (Eleutheronema tetradactylum) across northern Australia derived from life-history characteristics. Fisheries Research, 121-122: 63-72.

Bardhan, I.; Roy, S.; Mukhopadhyay, A. \& Tripathy, B. 2021. Ultrastructure of the sagittal otoliths in different body size groups of climbing perch Anabas testudineus (Anabantidae). Journal of Ichthyology, 61(1): 166-174.

Başusta, N. \& Khan, U. 2021. Sexual dimorphism in the otolith shape of shi drum, Umbrina cirrosa (L.), in the eastern Mediterranean Sea: Fish sizeotolith size relationships. Journal of Fish Biology, 99(1): 164-174. D0I

Bostanci, D.; Yilmaz, S.; Polat, N. \& Kontaş, S. 2012. The otolith biometry characteristics of black scorpionfish, Scorpaena porcus L., 1758. Black Sea Journal of Science, 2: 59-68.

Bremm, C.Q. \& Schulz, U.H. 2014. Otolith atlas of fish of the Sinos River. Brazilian Journal of Biology, 74(2): 274-282.

Butler, E.C.; Childs, A.-R.; Milner, M.V.; Farthing, M.W.; Duncan, M.I.; Winkler, A.C. \& Potts, W.M. 2021. Do contemporary age-growth models overlook life-history complexities in protandrous fishes? A case study on the large protandrous polynemid, the giant African threadfin Polydactylus quadrifilis. Fisheries Research, 233. DOI

Campana, S.E. \& Thorrold, S.R. 2001. Otoliths, increments, and elements: keys to a comprehensive understanding of fish population. Canadian Journal of fisheries and Aquatic Sciences, 58(1): 30-38.

Carvalho, B.M.; Volpedo, A.V. \& Fávaro, L.F. 2020. Ontogenetic and sexual variation in the sagitta otolith of Menticirrhus americanus (Teleostei; Sciaenidae) (Linnaeus, 1758) in a subtropical environment. Papéis Avulsos de Zoologia, 60(9):1-12. e20206009.

Dehghani, M.; Kamrani, E.; Salarpouri, A. \& Sharifian, S. 2016. Otolith dimensions (length, width), otolith weight and fish length of Sardinella sindensis (Day, 1878), as index for environmental studies, Persian Gulf, Iran. Marine Biodiversity Records, 9: 1-44.

Gierl, C.; Liebl, D.; Vukic, J.; Esmaeili, H.R. \& Reichenbacher, B. 2018. What can goby otolith morphology tell us. Cybium, 42(4): 349-363.
Gümüs, A. \& Kurt, A. 2009. Age structure and growth by otolith interpretation of Neogobius melanostomus (Gobiidae) from Southern Black Sea. Cybium, 33(1): 29-37.

Harvey, J.T.; Loughlin, T.R.; Perez, M.A. \& Oxman, D.S. 2000. Relationship between fish size and otolith length for 63 species of fishes from the eastern north Pacific Ocean. NOAA Technical Report NMFS, 150: 1-36.

Hunt, J.J. 1992. Morphological characteristics of otoliths for selected fish in the Northwest Atlantic. Journal of Northwest Atlantic Fishery Science, 13:63-75.

Jawad, L.A. 2007. Comparative morphology of the otolith of the triplefins (family: Tripterygiidae). Journal of Natural History, 41(13-16): 901-924.

Jawad, L.A.; Ambuali, A.; Al-MAmry, J.M. \& Al-Busaidi, H.K. 2011. Relationships between fish length and otolith length, width and weight of the Indian Mackerel Rastrelliger kanagurta (Cuvier, 1817) Collected from the Sea of Oman. Ribarstvo, 69: 51-61.

Jawad, L.A.; Hoedemakers, K.; Ibáñez, A.L.; Ahmed, Y.A.; El-Regal, M.A. \& Mehanna, S.F. 2018. Morphology study of the otoliths of the parrotfish, Chlorurus sordidus (Forsskål, 1775) and Hipposcarus harid (Forsskål, 1775) from the Red Sea coast of Egypt (Family: Scaridae). Journal of Marine Biological Association UK, 98(4): 819-828.

Kailola, P.J.; Williams, M.J.; Stewart, P.C.; Reichelt, R.E.; McNee, A. \& Grieve, C. 1993. Australian fisheries resources. Camberra, Bureau of Resource Science and Fisheries Research and Development Corporation. 422p.

Khedher, M.\& Fatnassi, M. 2018. Relationships between fish length otolith size of Diplodus Valgaris from Boughara and El Bibane Lagoons (Southeastern Tunisia). Research \& Reviews: Journal of Zoological. Sciences, 6(1): 43-50.

Kontaş, S. \& Bostanci, D. 2015. Morphology and biometrical characteristics on otolith of Barbus tauricus Kessler, 1877 on light and scanning electron microscope. International Journal of Morphology, 33(4): 1380-1385.

Kowtal, G.V. 1972. Observations on the breeding and larval development of Chilka 'Sahal' Eleutheronema tetradactylum (Shaw). Indian Journal of Fisheries, 19: 70-75.

Kumar, P.; Chakraborty, S.K. \& Jaiswar, A.K. 2012. Comparative otolith morphology of sciaenids occurring along the north-west coast of India. Indian Journal of Fisheries, 59(4): 19-27.

Lombarte, A. \& Lleonart, J. 1993. Otolith size changes related with body growth, habitat depth and temperature. Environmental Biology of Fishes, 37(3): 297-306.

Lombarte, A.; Rucabado, J.; Matallanas, J. \& Lloris, D. 1991. Taxonomía numérica de Nototheniidae en base a la forma de 10s otolitos. Scientia Marina, 55(2): 413-418.

McPherson, G.R. 1997. Reproductive biology of five target fish species in the Gulf of Carpentaria inshore gillnet fishery. In: Garrett, R.N. (Ed.). Biology and harvest of tropical fishes in the Queensland Gulf of Carpentaria gillnet fishery. Brisbane, Department of Primary Industries.103p. (FRDC Final Report 92/145)

Mehanna, S.F.; Jawad, L.A.; Ahmed, Y.A.; Abu El-Regal, M.A. \& Dawood, D. 2016. Relationships between fish size and otolith measurements for Chlorurus sordidus (Forsskal, 1775) and Hipposcarus harid (Forsskal, 1775) from the Red Sea coast of Egypt. Journal of Applied Ichthyology, 32(2): 356-358.

Mitsui, S.; Strüssmann, C.A.; Yokota, M. \& Yamamoto, Y. 2020. Comparative otolith morphology and species identification of clupeids from Japan. Ichthyological Research, 67(4): 502-513.

Motomura, H. 2004. An annotated and illustrated catalogue of polynemid species known to date. In: Carpenter, K. (Ed.). Threadfins of the world (Family Polynemidae). Rome, FA0. 117p. (FAO Species Catalogue for Fishery Purposes. No. 3).

Omar, A.M.S. \& AMohamed, S.Kh. 2016. Comparative morphological studies of otoliths (ear stones or crystals) in some marine and fresh water fishes. International Journal of Fisheries and Aquatic Studies, 4(6): 512-517. 
Omar, A.M.S. \& Moselhy, A.A.A. 2016. Comparative anatomical studies on the otoliths (Ear stones) of some fishes. International Journal of Fisheries and Aquatics Studies, 4(6): 506-511.

Önsoy, B.; Tarkan, A.S.; Filiz, H. \& Bilge, G. 2011. Determination of the best length measurement of fish. Western Journal of Zoology, 7(1): 178-180.

Patnaik, S. 1967. Hermaphroditism in the Indian salmon Eleutheronema tetradactylum (Shaw). Current Science, 36(19):1-525.

Popper, A.N. \& Hoxter, B. 1981. The fine structure of the sacculus and lagena of a teleost fish. Hearing Research, 5(2-3): 245-263.

Popper, A.N. \& Lu, Z. 2000. Structure-function relationships in fish otolith organs. Fisheries Research, 46(1-3): 15-25.

Popper, A.N.; Ramcharitar, J. \& Campana, S.E. 2005. Why otoliths? Insights from inner ear physiology and fisheries biology. Marine and Freshwater Research, 56(5): 497-504.

Pracheil, B.M.; George, R. \& Chakoumakos, B.C. 2019. Significance of otolith calcium carbonate crystal structure diversity to microchemistry studies. Reviews in Fish Biology and Fisheries, 29(3): 569-588.

Rodríguez Mendoza, R.P. 2006. Otoliths and their applications in fishery science. Ribarstvo, 64(3): 89-102.

Ruck, J.G. 1976. Studies on the development and osteology of some New Zealand inshore fishes. PhD thesis, Wellington, New Zealand, Victoria University.

Sadovy, Y. \& Liu, M. 2008. Functional hermaphroditism in teleosts. Fish and Fisheries, 9: 1-43.

Sanchez, R.0. \& Martinez, V.H. 2017. Morphologiccal variations of the three otoliths of some species of the family Loricariidae (Ostariophysi: Siluriformes). Neotropical Ichthyology, 15(1): e160058[1]-e160058[11].

Santificetur, C.; Conversani, V.R.M.; Nunes, M.R.B.; Giaretta, M.B.; Siliprandi, C.C. \& Wongtschowski, C.L.D.B.R. 2017. Atlas of marine bony fish otoliths (sagittae) of Southeastern-Southern Brazil Part V: Perciformes (Sparidae, Sciaenidae, Polynemidae, Mullidae, Kyphosidae, Chaetodontidae, Mugilidae, Scaridae, Percophidae, Pinguipedidae, Blenniidae, Gobiidae, Ephippidae,Sphyraenidae, Gempylidae, Trichiuridae, Scombridae, Ariommatidae, Stromateidae, and (aproidae). Brazilian Journal of Oceanography, 65(3): 201-257.

Schwarzhans, W. \& Grenfell, H.R. 2002. The fish otolith faunas of early Nukumaruan sites at Hawke's Bay and Waipukurau. Proceedings of the Taupaki Malacological Society, 3: 1-23.

Skeljo, F. \& Ferri, J. 2012. The use of otolith shape and morphometry for identification and size-estimation of five wrasse species in predator-prey studies. Journal of Applied Ichthyology, 28(4): 524-30.

Smale, M.J.; Watsony, G. \& Hecht, T. 1995. Otolith atlas of Southern African marine fishes. Grahamstown (South Africa), J.L.B. Smith Institute of Ichthyology. 253p. (monograph 1)

Stanger, J.D. 1974. A study on the growth, feeding, and reproduction of the threadfin, Eleutheronema tetradactylum (Shaw). Unpublished Honours Thesis. Townsville, James Cook University of North Queensland. 126p.

Vallisneri, M.; Trotta, V.; Cavicchi, S. \& Piccinetti, C. 2008. Sex-specific somaticotolith growth relationship in two Gadidae. Journal of Fish Biology, 72(3): 724-730.

Vilizzi, L. 2018. Age determination in common carp Cyprinus carpio: history, relative utility of ageing structures, precision and accuracy. Reviews in Fish Biology and Fisheries, 28(3): 461-484.

Volpedo, A. \& Echevarria, D.D. 2003. Ecomorphological patterns of the sagitta in fish on the continental shelf off Argentine. Fisheries Research, 60(2-3): 551-560.

Yilmaz, S.; Yazicioglu, 0.; Yazici, R. \& Polat, N. 2015. Relationships between fish length and otolith size for five cyprinid species from Lake Ladik, Samsun, Turkey. Turkish Journal of Zoology, 39(3): 438-446. 